\title{
DAYA BUNUH EKSTRAK DAUN TOMAT (Solanum lycopersicum L.) TERHADAP LARVA NYAMUK Aedes aegypti
}

\author{
Setyo Dwi Santoso ${ }^{1)}$, Abdul Chamid ${ }^{2}$, Dwi Viddi Kusuma Pratiwi ${ }^{3)}$ \\ ${ }^{1), 2)}$ Dosen Fakultas Ilmu Kesehatan, Universitas Maarif Hasyim Latif Sidoarjo \\ ${ }^{3)}$ Mahasiswa DIII Teknologi Laboratorium Medik, Universitas Maarif Hasyim Latif Sidoarjo
}

setyo.dwi@dosen.umaha.ac.id

\begin{abstract}
Dengue hemorrhagic fever (DHF) is a very dangerous disease, caused by Aedes aegypti mosquitoes. One alternative to controlling Aedes aegypti mosquitoes is to use insecticides. But it would be much better if the insecticides used are natural and environmentally friendly, one of them by using Tomato Leaf Extract (Solanum lycopersicum 1.). Tomato leaves contain chemical compounds class Alkaloids and Saponins and can serve as anti larvacide. This research is a laboratory experiment which aims to find out the effect of tomato leaf extract (Solanum lycopersicum L.) activity on the death of III instar larvae of Aedes aegypti mosquito. the effectiveness of samples on Aedes aegypti mosquito larvae by treatment of variation of extract concentration $0.2 \%, 0.4 \%, 0.6 \%, 0.8 \%, 1 \%$ with repetition 2 times. In the results of research showed that the smallest concentration that can kill Aedes aegypti mosquito larvae is $0.6 \%$ at 16 hours and probit analysis showed that significance is 0,608 greater than intercept 0.003 , it shows that the extract of tomato leaves affects the death of III instar larvae of Aedes aegypti mosquito.
\end{abstract}

Keywords: III instar larvae of Aedes aegypti mosquito, tomato leaves, larvicide

\section{PENDAHULUAN}

Aedes aegypti adalah jenis nyamuk yang merupakan vektor utama penyakit Demam Berdarah Dengue (DBD). Seperti halnya penyakit malaria yang disebabkan oleh parasit protozoa yang disebut plasmodium, ditularkan dari penderita ke orang yang sehat oleh nyamuk Anopheles (Nopianti, 2000). Senyawa ligan dan organologam besi(III) dapat digunakan sebagai aktivitas antimalaria dengan mekanisme inhibisi enzim PbDHFR lebih tinggi dibandingkan dengan pirimetamin. Nilai IC50 senyawa organologam besi (III) sebesar ppm 23,911 ppm, senyawa ligan sebesar $27.380 \mathrm{ppm}$ dan senyawa pirimetamin sebesar 215.349 ppm (Dwi, 2011).

Penyakit Virus demam dengue ini menyebar luas di negara tropis seperti Asia, India, Karbia, Afrika Tengah dan Selatan, serta Meksiko. Aedes aegypti mengalami metamorfosis sempurna. Terdapat empat tahapan dalam perkembangan larva yang disebut instar. Perkembangan dari instar I ke instar IV memerlukan waktu sekitar lima hari. Setelah mencapai instar IV, larva berubah menjadi pupa di mana larva memasuki masa dorman. Pupa bertahan selama dua hari sebelum akhirnya nyamuk dewasa keluar dari pupa. Perkembangan dari telur hingga nyamuk dewasa membutuhkan waktu tujuh hingga delapan hari, namun bisa lebih lama bila kondisi lingkungan tidak mendukung (Sembel, 2009).

Demam Berdarah Dengue atau Dengue Hmorrhagic Fever (DHF) adalah penyakit virus yang berbahaya karena penderita dapat meninggal dalam waktu yang sangat pendek (beberapa hari). Penyakit ini masuk ke indonesia sejak 1968 melalui pelabuhan surabaya, dan pada tahun 1980 DBD telah dilaporkan secara luas melanda seluruh provinsi di Indonesia (Ellyfas, 2012). Berbagai upaya dapat dilakukan untuk mengontrol populasi nyamuk ini dengan tujuan utama adalah menurunkan populasi nyamuk Aedes aegypti sehingga kemampuan sebagai vektor akan menghilang dengan cara kimiawi, biologik, radiasi, mekanik terhadap telur, larva, pupa, dewasa maupun terhadap tempat perindukannya dengan menggunakan insektisida (Palgunadi, 2011).

Mencermati berbagai dampak maupun risiko penggunaan insektisida sintetis, maka perlu dicari cara lain yang lebih ekonomis, tidak menimbulkan dampak terhadap manusia 
tetapi dapat bermanfaat untuk pemberantasan vektor. Oleh karena itu, penggunaan insektisida nabati atau botanik yang bersifat alamiah dalam pengendalian vektor umumnya dilakukan pada stadium jentik atau larvasida (Listiyati, 2012).

Larvasida alami merupakan larvasida yang dibuat dari tanaman yang mem- punyai kandungan beracun terhadap serangga pada stadium larva. Penggunaan larvasida alami ini diharapkan tidak mempunyai efek samping terhadap lingkungan, manusia dan tidak menimbulkan resistensi bagi serangga. Salah satu jenis tanaman yang mempunyai potensi sebagai sumber larvasida nabati adalah serai (Andropogon nardus). Kandungan kimia serai lebih banyak terdapat pada batang dan daun, dan kandungan yang paling besar yaitu sitronela sebesar $35 \%$ dan geraniol sebesar 35 $40 \%$ (Nugroho, 2011). Selain itu juga tanaman yang mempunyai potensi sebagai sumber larvasida nabati antara lain kulit jeruk nipis (Citrus aurantifolia) yang dapat membunuh $50 \%$ (IC50) larva nyamuk Aedes aegypti adalah 3,419\% dalam waktu 24 jam (Ekawati, 2017), daun pepaya (Farid, 2015), buah lerak (Isrianto, 2017) dan daun legundai (Cania, 2013).

Berdasarkan uraian di atas, penulis melakukan penelitian mengenai pemanfaatan jenis tanaman lain yaitu daun tomat (Solanum lycopersicum L) sebagai larvasida nyamuk Aedes aegypti instar III. Pada daun dan batangnya tomat juga terdapat senyawa alkaloid dan saponin yang bisa digunakan sebagai insektisida. Alkaloid ini merupakan senyawa yang bisa bersifat racun dan menggagalkan proses metamorphosis dan saponin merupakan senyawa aktif yang bersifat seperti sabun sehingga mampu membunuh jentik nyamuk DBD. Selain itu, senyawa aktif alkaloid memiliki aktivitas hipoglikemik atau penurun kadar glukosa seperti pada tanaman jintan hitam dan minyak zaitun terhadap penurunan kadar glukosa darah dan dapat menurunkan tekanan darah (Santoso, 2017). Sedangkan saponin dapat berfungsi sebagai antimikroba untuk bakteri dan virus (Kendran, 2013)

\section{METODOLOGI PENELITIAN}

Penelitian ini merupakan penelitian eksperimen yaitu untuk mengetahui potensi ekstrak Daun Tomat (Solanum lycopersicum L) sebagai larvasida Aedes aegypti. Karena dalam penelitian ini, peneliti memperlakukan populasi sebagai treatment dan juga menggunakan kontrol, sehingga peneliti ini tergolong sebagai true eksperimen.

\section{Waktu dan Tempat Penelitian}

Tempat penelitian ini dilakukan di Laboratorium Fakultas Kesehatan Teknologi Laboratorium Parasitologi Universitas Hasyim Latif (UMAHA) Sidoarjo. Waktu penelitian dilaksanakan selama 4 bulan.

\section{Pembuatan Ekstrak Daun Tomat}

Daun tomat diiris menjadi beberapa bagian, kemudian di angin-anginkan sampai kering ( tidak boleh di jemur dibawah sinar matahari lansung lalu ditimbang ). Setelah kering dihaluskan dengan blender, untuk dijadikan serbuk. Serbuk daun tomat direndam dengan etanol selama 3 hari dan setiap harinya dilakukan diaduk setiap 2 jam sekali. Lalu disaring dan diambil fitratnya kemudian divacuum evaporator.

\section{Uji Larvasida Ekstrak Daun Tomat}

Menyiapkan 6 gelas plastik masing masing $225 \mathrm{~mL}$ berisi akuades dan 2 buah gelas plastik untuk kontrol negatif yang berisi masing - masing $250 \mathrm{ml}$ pelarut Aquades. Selanjutnya memiipet ekstrak daun tomat dengan variasi konsentrasi 0,2\%, 0,4\%, 0,6 $\%$, 0,8 \%, dan 1\%. Kemudian memasukkan masing - masing kedalam gelas yang telah berisi aquades $225 \mathrm{~mL}$, diaduk selama 30 detik dan didiamkan selama 15 menit.

Kemudian diambil larva sebanyak 25 ekor dengan menggunakan pipet Pasteur. Kemudian memasukkan larva tersebut ke dalam beaker glass yang sudah berisi $24 \mathrm{~mL}$ aquades. Selanjutnya larva dituang kedalam gelas plastik yang berisi ekstrak dan dilakukan pengamatan dalam varian waktu 4 jam, 8 jam, 12 jam, 16 jam sampai 24 jam dengan replikasi 2 kali.

\section{Analisa Data}

Data yang diperoleh dianalisis secara statistik dengan uji Analisis Probit menggunakan program SPSS 16.0.

\section{HASIL DAN PEMBAHASAN \\ Hasil Pengamatan Kematian Larva}

Dari Daun Tomat sebanyak $1,5 \mathrm{~kg}$, dari hasil evaporasi Daun Tomat didapatkan ekstrak kental sebanyak 25 gr. Kemudian 
dibuat konsentrasi $0,2 \%, 0,4 \%, 0,6 \%, 0,8 \%$ dan $1 \%$. Setelah mendapatkan ekstrak Daun Tomat peneliti melanjutkan pemeriksaan larva Aedes aegypti. Larva tersebut didapatkan dari Laboraturium Entamologi Dinas Kesehatan Provinsi Jawa Timur sebanyak \pm 250 ekor dan membagi 25 ekor ke masing - masing konsentrasi yang akan diuj mulai $0,2 \%$ sampai dengan $1 \%$ dengan akuades kontrol negatif. Berdasarkan data hasil pengamatan menunjukkan larva Aedes aegypti instar III yang mati pada masing - masing konsentrasi (\%). Data hasil pengamatan disajikan pada Tabel 1.

Tabel 1. Hasil pengamatan dari kematian larva nyamuk Aedes aegypti

\begin{tabular}{|c|c|c|c|c|c|c|c|c|c|c|c|c|c|c|c|c|}
\hline \multirow{3}{*}{$\begin{array}{l}\text { Waktu } \\
\text { (Jam) }\end{array}$} & \multicolumn{16}{|c|}{ Jumlah Larva Yang Mati Dengan Berbagai Konsentrasi $(\mathbf{n}=\mathbf{2 5})$} \\
\hline & \multirow{2}{*}{ K (-) } & \multicolumn{3}{|c|}{ К 0,2\% } & \multicolumn{3}{|c|}{ К $0,4 \%$} & \multicolumn{3}{|c|}{ К $0,6 \%$} & \multicolumn{3}{|c|}{ К 0,6\% } & \multicolumn{3}{|c|}{ K 1\% } \\
\hline & & $\mathrm{P} 1$ & $\mathrm{P} 2$ & Rata2 & P1 & $\mathrm{P} 2$ & Rata2 & P1 & $\mathrm{P} 2$ & Rata2 & $\mathrm{P} 1$ & $\mathrm{P} 2$ & Rata2 & P1 & $\mathrm{P} 2$ & Rata2 \\
\hline 4 & $\mathbf{0}$ & 0 & 0 & $\mathbf{0}$ & 3 & 4 & 3,5 & 7 & 8 & 7,5 & 10 & 9 & 9,5 & 17 & 18 & 17,5 \\
\hline 8 & 0 & 0 & 0 & 0 & 7 & 9 & 8 & 15 & 17 & 16 & 23 & 19 & 21 & 24 & 24 & 24 \\
\hline 12 & 0 & 5 & 4 & 4,5 & 13 & 17 & 15 & 23 & 23 & 23 & 25 & 25 & 25 & 25 & 25 & 25 \\
\hline 16 & 0 & 9 & 9 & 9 & 16 & 20 & 18 & 25 & 25 & 25 & 25 & 25 & 25 & 25 & 25 & 25 \\
\hline 20 & 0 & 12 & 13 & 12,5 & 18 & 21 & 19,5 & 25 & 25 & 25 & 25 & 25 & 25 & 25 & 25 & 25 \\
\hline 24 & 0 & 16 & 15 & 15,5 & 20 & 22 & 21 & 25 & 25 & 25 & 25 & 25 & 25 & 25 & 25 & 25 \\
\hline
\end{tabular}

Dari hasil penelitian, ekstrak daun tomat dengan konsentrasi $1 \mathrm{~mL}$ menunjukkan tingkat kematian $96 \%$. Larva dilakukan selama 4 jam sampai 24 jam. Konsentrasi terkecil yang dapat membunuh larva nyamuk Aedes aegypti adalah $0,6 \%$ pada waktu 16 jam.

Kemampuan larvasida dipengaruhi oleh faktor konsentrasi dan waktu interaksi antara larvasida dengan larva nyamuk. Semakin besar konsentrasi larvasida yang digunakan dan semakin lama interaksi antara larvasida dengan larva nyamuk, maka semakin besar kemampuan larvasid tersebut untuk dapat mematikan larva nyamuk seperti disajikan pada Grafik 1.

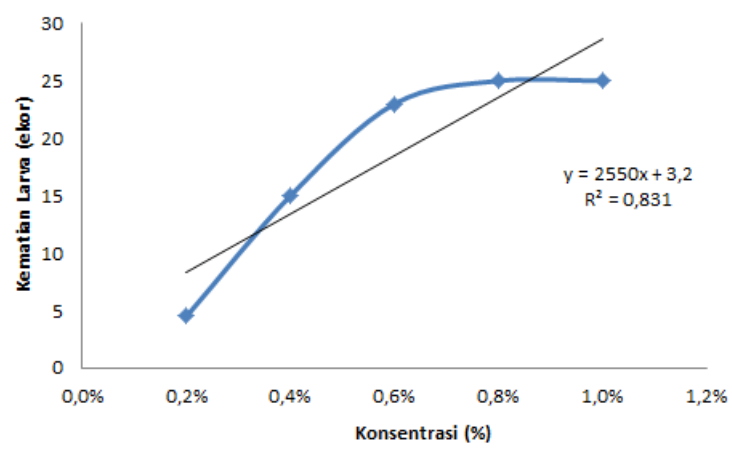

(a)

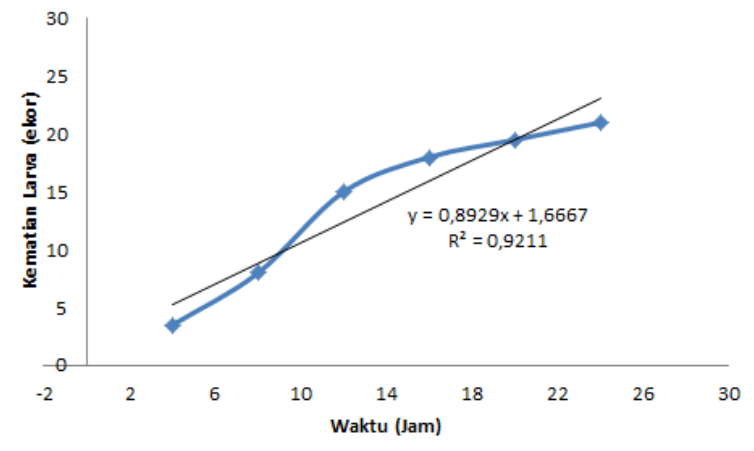

(b)

Grafik 1. Pengaruh konsentrasi (a) dan waktu interaksi (b) antara larvasida dengan larva nyamuk

Dari hasil penelitian kemudian dilakukan analisa data menggunakan analisis probit di dapat nilai signifikansi sebesar 0,608 . Nilai tersebut lebih besar dari intercept 0,003. Hal ini menunjukkan bahwa ekstrak daun tomat dengan berbagai konsentrasi ada pengaruh dalam kematian larva Aedes aegypti Instar III.

Kemampuan daun tomat dalam membunuh larva nyamuk Aedes aegypti Instar III di karenakan adanya kandungan Saponin dan Alkaloid. Saponin adalah jenis glikosida yang banyak di temukan dalam tumbuhan. Saponin mudah larut dalam air dan saponin memiliki rasa pahit menusuk dan menyebabkan iritasi pada selaput lendir. Saponin merupakan racun yang dapat menghancurkan butir darah atau hemolisis pada darah. Sedangkan Alkaloid ini merupakan senyawa yang bisa bersifat racun dan menggagalkan proses metamorphosis.

\section{KESIMPULAN}

Dari hasil penelitian dapat disimpulkan konsentrasi terkecil ekstrak daun tomat digunakan sebagai larvasisa nyamuk Aedes 
aegypti adalah $0,6 \%$ pada waktu 16 jam.

\section{DAFTAR PUSTAKA}

Cania, E., \& Setyanimgrum, E. (2013). Uji Efektivitas Larvasida Ekstrak Daun Legundi (Vitex trifolia) terhadap Larva Aedes aegypti. Medical Journal of Lampung University, 52(4), 52-60.

Dwi, S. (2011). Sintesis Dan Uji Antimalaria Senyawa Organologam Besi(Iii), (Iii), 4-7.

Ekawati, E. R., Santoso, S. D., \& Purwanti, Y. R. (2017). PEMANFAATAN KULIT BUAH JERUK NIPIS (Citrus aurantifolia) SEBAGAI LARVASIDA Aedes aegypti INSTAR III. Jurnal Biota Edisi Januari, $3(1), 1-5$.

Ellyfas, K., Suprobowati, O. D., \& SSBU, D. (2012). Pengaruh Pemberian Ekstrak Buah Nanas (Ananas comosus (L.)Merr.) terhadap Kematian Larva Aedes aegypti. Jurnal Analisis Kesehatan.

Farid, A. M. (2015). Effectivity Of Papaya Leaves ( Carica papaya 1 ) As Inhibitor Of Aedes Aegypti Larvae, 4, 2-5.

Isrianto, P. L., \& Kristianto, S. (2017). PERBANDINGAN EKSTRAK ETANOL BUAH LERAK DAN ABATE TERHADAP MORTALITAS LARVA Aedes aegypti Instar III 1,2), (September), 492-500.

Kendran, A.A.S., , Gelgel, Pertiwi, Anthara, Dharmayuda, Anggreni, L.D. (2013). Toksisitas Ekstrak Daun Sirih Merah pada Tikus Putih Penderita Diabetes Melitus, Jurnal Veteriner, 14(4), 527-533.

Listiyati, A. K., Nurkalis, U., \& Hestiningsih, R. (2012). Ekstraksi Nikotin Dari Daun Tembakau ( Nicotina Tabacum ) dan Pemanfaatannya sebagai Insektisida Nabati Pembunuh Nyamuk Aedes sp. Jurnal Ilmiah Mahasiswa, 2(2), 67-70.

Nopianti, S., \& Astuti, D. (2000). Efektivitas Buah Belimbing Wuluh (Averrhoa bilimbi L .) untuk Membunuh Larva Nyamuk Anopheles aconitus Instar III. Jurnal Kesehatan, 1(2), 103-114.

Nugroho, A. D. (2011). Kematian Larva Aedes aegypti Setelah Pemberian Abate Di bandingkan Dengan Pemberian Serbuk Serai. Jurnal Kesehatan Masyarakat, 7(1), 91-96. https://doi.org/ISSN 1858-1196

Palgunadi, B. U., \& Rahayu, A. (2011). Dengue Aedes aegypti As Dengue Haemorrhagic Fever Vector. Lecturer Faculty of Medicine.
Santoso, S. D., \& Suryanto, I. (2017). KOMPARASI EFEK PEMBERIAN MINYAK JINTAN HITAM (Nigella sativa) DENGAN MINYAK ZAITUN (Olea europea) TERHADAP PENURUNAN GLUKOSA DARAH PADA MENCIT (Mus musculus) STRAIN Balb/c. SainHealth, 1(1),s 36-42. 